\title{
Design and Implementations of Control System Quadruped Robot Driver Application Based on Windows Platform
}

\author{
Made Sudarma, IBA. Swamardika, IW. Dani Pranata. \\ Department of Electrical and Computer Engineering, Faculty of Engineering, Udayana University, Bali, Indonesia
}

\begin{tabular}{l}
\hline \hline Article Info \\
\hline Article history: \\
Received Nov 25, 2014 \\
Revised Jan 20, 2015 \\
Accepted Feb 7, 2015 \\
\hline
\end{tabular}

\section{Keyword:}

Controller application

Quadruped robot

Robotic controller

Xbee-PRO

\begin{abstract}
Wireless remote device control system is a controlling method which is widely used in various fields. By using wireless communication media, remote control system becomes more efficient and flexible. Computer application is one of the devices which can be used to perform remote controlling. Computer application can be made in accordance with the need of its users in conducting device controlling from the distance. Remote controlling is also can be applied on the robotic field. One of the examples is wireless remote controlling of Quadruped Robot. By utilizing its Windows application such as Visual Basic in order to establish communication with wireless communication module such as Xbee-PRO, a control system can be designed which can be used to control the movement of Quadruped Robot wirelessly. Wireless communication module is also has to be installed and able to perform data communication with the device to be controlled that is Quadruped Robot. The addition of camera which is also using wireless communication system will be very helpful for the users in knowing the condition around Quadruped Robot.
\end{abstract}

Copyright (C) 2015 Institute of Advanced Engineering and Science. All rights reserved.

\section{Corresponding Author:}

Dr. Ir. Made Sudarma, M.A.Sc.,

Departement of Electrical and Computer Engineering,

Engineering Faculty, Udayana University,

Jimbaran Campus, Kuta 80361, Bali, Indonesia.

Email: msudarma@ee.unud.ac.id, Telp./Fax. : +62361703315

\section{INTRODUCTION}

Computer application is a series of computer software which is using the capability of the computer itself to perform certain tasks according to the wish of its users to achieve certain objective. Computer applications are vastly made and developed for various things, such as word, number and picture processing, and many other purposes [1-5]. The development and creation of computer application is not limited only on the factories or development companies and computer manufacturers [6]. Almost anybody who is mastering a programming language can create their own computer applications, as well as developing the existing computer application. Computer application is also can be used to perform the job outside of the computer, such as performing the controlling towards the device outside of the computer [7].

In this study a windows application will be designed which will be used to perform the controlling towards a movement of fout-footed robot, or can be called with Quadruped Robot, from the distance. Windows application acts as the command sender, whereas Quadruped Robot acts as the command receiver. The transmission of command instruction is conducted through wireless communication media by using Xbee-Pro wireless module. Wireless communication media is selected since the transmission process of command instruction will not disturb the movement of Quadruped Robot. The movement of Quadruped Robot which can be controlled, among others, walking forward, walking backward, walking to the left side and to the right side, the setting of robot's altitude, and crisscrossing to the left side and to the right side on certain angles [8-10]. 


\section{RESEARCH METHOD}

The following activity of research and described of the research method such as:

\subsection{Software design}

1. Visual Basic 2008 Express Edition: It is used to develop other application based on Windows operating system. In this study, Visual Basic 2008 Express Edition application will be used to develop application to control the movement of Quadruped Robot [8].

2. Codevision AVR: It is used to perform the programming for the microcontroller Integrated Circuit (IC) which is a main processing unit presence in Quadruped Robot. In this study, Codevision AVR application will be used to perform programming on Quadruped Robot $[1,10]$.

3. X-CTU software: It is used to perform configuration for XBee wireless module. Besides for performing configuration, X-CTU software also has some other facilities such as, PC Setting, Range Test, and Terminal. PC Setting facility is used to perform connection trial between PC and XBee module. Range Test facility is used to perform the accuracy measurement of data transmission and receiving by 2 XBee modules in the certain distance [2]. Terminal facility is used to display the data being transmitted and received by XBee modules.

\subsection{Hardware design}

1. XBee-PRO Series $I 60 \mathrm{~mW}$ : is an electronic module used to perform data communication wirelessly. Protocol standard being used is ZigBee which refers to the standard of IEEE 802.15.4. Working frequency being used is $2.4 \mathrm{Ghz}$, with the range of indoor communication as far as 133 feet or 40 meters, and the range of outdoor communication as far as 400 feet or 120 meters. The speed of RF (Radio Frequency) data transfer is $250,000 \mathrm{bps}$, and the speed of serial communication data transfer is $1,200 \mathrm{bps}$ up to $1 \mathrm{Mbps}$. For the system to work properly, XBee-PRO Series I $60 \mathrm{~mW}$ requires power supply of 2.8 $\mathrm{V}_{\mathrm{DC}}$ up to $3.3 \mathrm{~V}_{\mathrm{DC}}[2,5]$.

2. ATmega1280: It is a microcontroller IC which is being manufactured by Atmel from the family of AVR (Alf and Vegard's Rise). ATmega1280 has a package form of TQFP (Thin Profile Plastic Quad Flat Package). ATmega1280 is selected as main processing unit, since it has flash memory to store program of 128 KiloByte, and adequate facility to perform all the process to drive Quadruped Robot. The facility includes, 4 units of 16-bit timers to drive each foot of Quadruped Robot, the speed of instruction execution up to 16 MIPS (Million Instructions per Second), 54/86 I/O (Input/Output) ports which can be programmed, USART serial communication to communicate with XBee-PRO Series I $60 \mathrm{~mW}$ module $[4,6]$.

3. Servo Motor: It is a DC motor which its shaft rotation angle can be set by providing certain PWM (Pulse Width Modulation) pulse value to the servo motor. PWM is a square wave signal with fixed frequency, but having a ratio of high pulse and low pulse that can be set [3]. In each foot of Quadruped Robot uses 1 unit of servo motor HS-225MG, and 2 units of HS-645MG. These two types of servos have angular movement range of 180 degree. Servo motor HS-645MG has a physical form and torque which is greater than servo HS-225MG. Servo HS-225MG has a torque reaching $4.8 \mathrm{~kg} . \mathrm{cm}$, whereas servo HS-645MG has a torque reaching $9.6 \mathrm{~kg} . \mathrm{cm}$. Figure 1 is a laying system of servo HS-225MG in the coxa section.

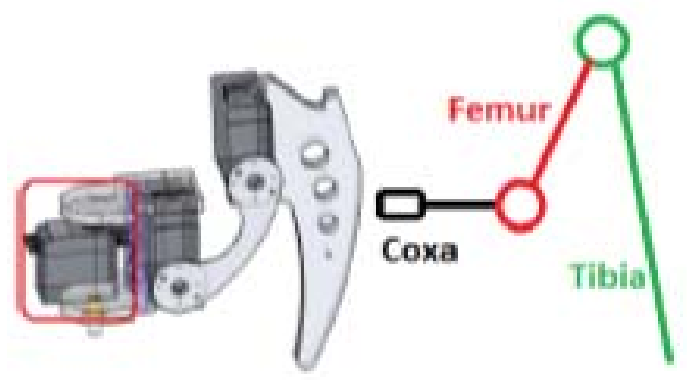

Figure 1. Design of HS-225MG servo motor 


\subsection{The Design of Quadruped Robot}

Quadruped Robot acts as an entity which its movement will be controlled. Quadruped Robot uses microcontroller ATmega1280 as a control unit and main processing unit. In Figure 2 the main driver on each foot of Quadruped Robot is using servo motor HS-225MG and HS-645MG which is used as a motor. Each foot of Quadruped Robot has 3 DOF (Degree of Freedom).

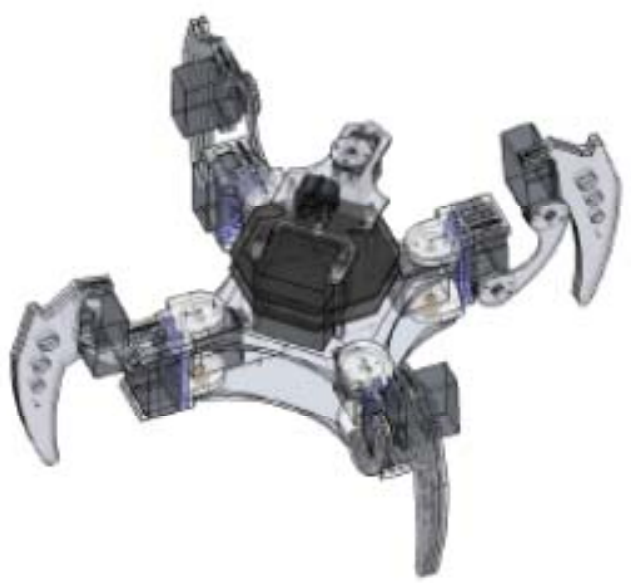

Figure 2. Design of physical form of quadruped robot

There are four main entities which are inter-connected and each has an important role. The four entities are, 1 unit laptop or PC with Windows operating system, 2 units of XBee-PRO Series I $60 \mathrm{~mW}$, one Quadruped Robot, one wireless camera, and one wireless camera receiver. The utilization of wireless camera device is intended to help finding out the situation around Quadruped Robot, when the position of Quadruped Robot is out of view or blocked by certain thing [2]. Figure 3 is the direction of data flow and the process performed, during the controlling process, the movement of Quadruped Robot is using application based on Windows.

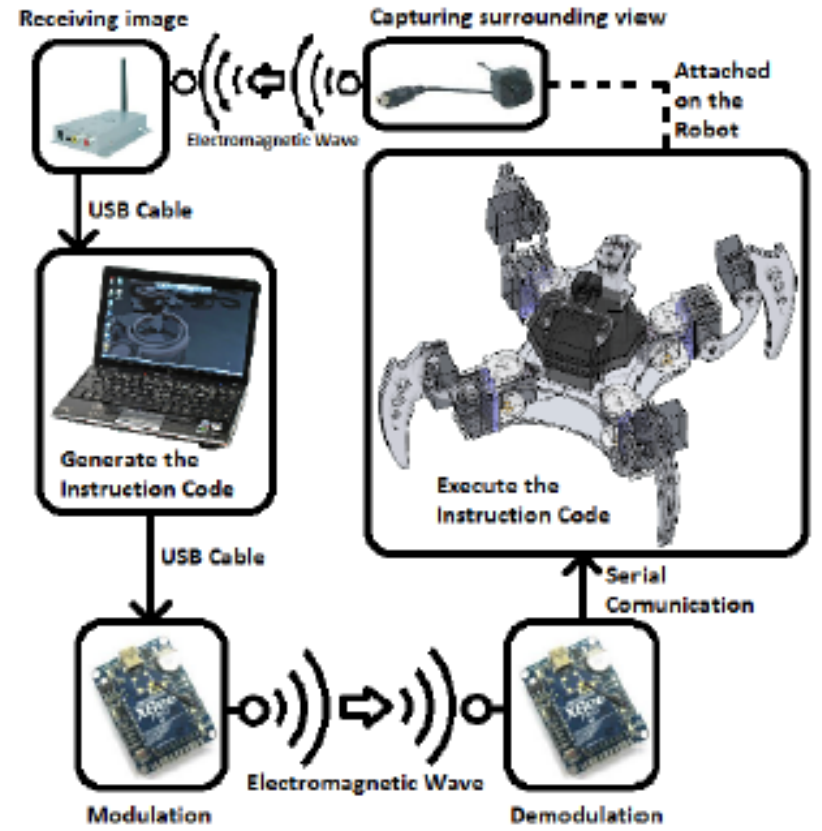

Figure 3. Direction of data flow the movement of quadruped robot 
The design of controller application being developed, it has a quite simple display. The function of every existing button and control facility is equipped with icon representing the function of that button or control facility. There are 18 facilities owned by the controller application, consists of 12 control facilities and 6 display facilities. Besides it is using the facilities on the controller application, some buttons on the keyboard also can be used to provide instructions to Quadruped Robot. The utilization of some keyboard's buttons is limited only to several simple instructions [9].

The action or value change carried out on each control facility will be interpreted as giving an order and the transmission process of command value will be carried out 5 times to the Quadruped Robot, in accordance with command value being owned or referred on the concerned control facility. The repeated data transmission of 5 times is aimed to reduce the risk of the occurrence of reading errors due to the loss of data or damaged data. Table 1 is a correlation between command value being transmitted and the movement which will be performed by the Quadruped Robot.

Table 1. Correlation between command value and the movement of Quadruped Robot.

\begin{tabular}{|c|c|c|}
\hline $\begin{array}{c}\text { Value } \\
\text { Transmitted }\end{array}$ & Objective Activity & Facility Being Used \\
\hline 0 & Rest & Button "F" or radio button "Rest" on controller software \\
\hline 1 & Backward & Button "S" or backward button on controller software \\
\hline 2 & Forward & Button "W" or forward button on controller software \\
\hline 3 & Left & Button "A" or left button on controller software \\
\hline 4 & Right & Button "D" or right button on controller software \\
\hline 5 & Standby ready & $\begin{array}{c}\text { Button "F" or button pause or radio button "Ready" on controller software } \\
\text { Track bar no. } 9\end{array}$ \\
\hline $10-76$ & Setting of camera angle $0^{0}$ - & \\
\hline $77-86$ & $\begin{array}{c}300^{\circ} \\
\text { Setting of horizontal angle } \\
\text { of robotic body } 0^{\circ}-50^{\circ}\end{array}$ & Track bar no. 10 \\
\hline $87-105$ & $\begin{array}{l}\text { Setting of robot's altitude } \\
0^{0}-180^{\circ}\end{array}$ & Track bar no. 12 \\
\hline $106-116$ & $\begin{array}{l}\text { Instruction of left or right } \\
\text { crisscrossing } 0^{0}-50^{\circ}\end{array}$ & Track bar no. 11 \\
\hline
\end{tabular}

Video display application is an additional application which can be accessed from controller application that will be used to display the video received from wireless camera. The source of picture or video is obtained from camera receiver connected with PC or laptop by using USB cable. Video display application has a simpler display compared with controller application. Video display application has 4 facilities, among others, 3 control facilities and one display facility.

\section{RESULTS AND ANALYSIS}

Physical form of Quadruped Robot which acts as the entity controlled by its movement, is shown with the following Figure 4. 


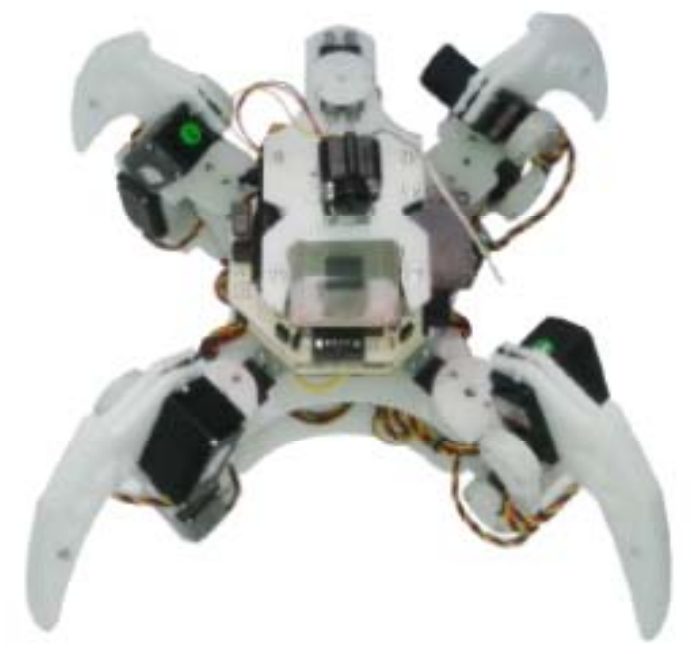

Figure 4. Physical performance of quadruped robot

The result of controller application based on Windows when the command "rest" is activated, is shown with Figure 5 whereas Figure 6 is a display when the command "ready" is activated. The numbering in red with moderate size, which laid on each of controller application facility, is intended to help explain the description of each facility.

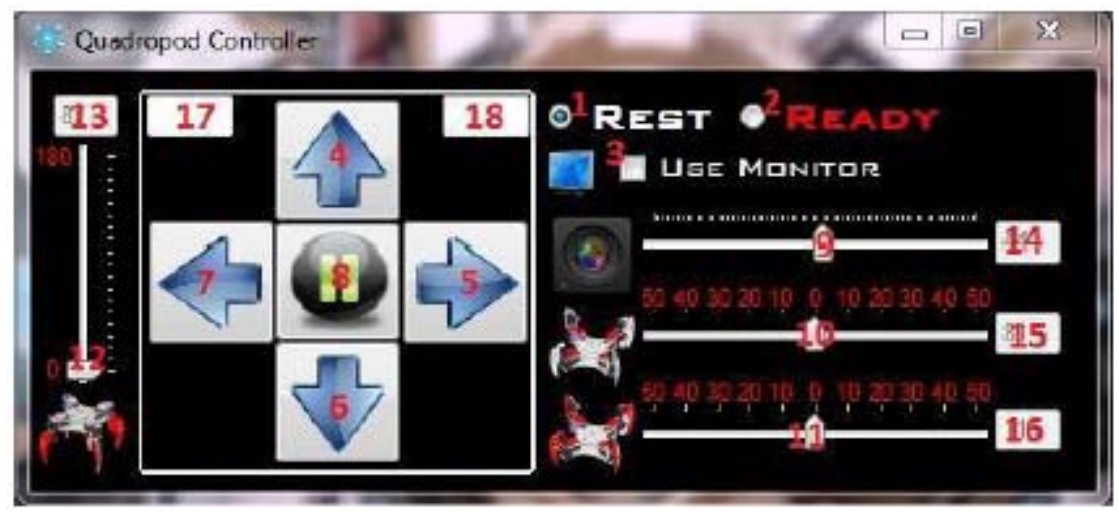

Figure 5. Controller applications display with active rest

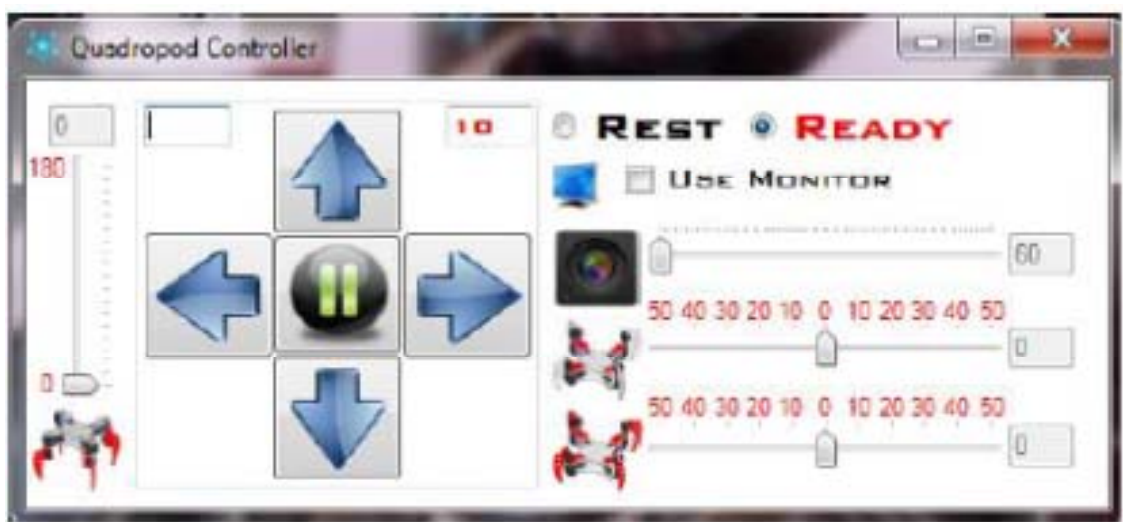

Figure 6. Controller applications display with ready active 
The description of each facility is in accordance with the numbering which has been stated, as follows:

1. Radio Button is to give rest instruction to the Quadruped Robot.

2. Radio Button is to give standby instruction or ready to receive instruction from controller software.

3. Check Box is to activate the use of monitor on controller software to display the picture obtained from wireless camera.

4. Forward Button, to give command for walking forward.

5. Right Button, to give command for walking toward the right.

6. Backward Button, to give command for walking backward.

7. Left Button, to give command for walking toward the left.

8. Standby Button, to give command to standby.

9. Track Bar to drive the camera.

10. Track Bar to direct horizontal angle of Quadruped Robot toward vertical axis. The change of the angle is carried out when Quadruped Robot is in the state of motionless.

11. Track Bar to give instruction to turn in the place.

12. Track Bar to adjust the altitude of the robot. This motion is performed when Quadruped Robot is in the state of motionless

13. Text Box to display the altitude value pointed by the track bar of altitude regulator.

14. Text Box to display the camera angle value pointed by the track bar of camera angle regulator.

15. Text Box which is being used to display the horizontal angle value pointed by the track bar of horizontal angle regulator of Quadruped Robot.

16. Text Box which is being used to display the turning angle value pointed by the track bar of turning angle regulator.

17. Text Box to display the letter of the button pressed on the keyboard to give command.

18. Text Box to display the value of instruction being transmitted.

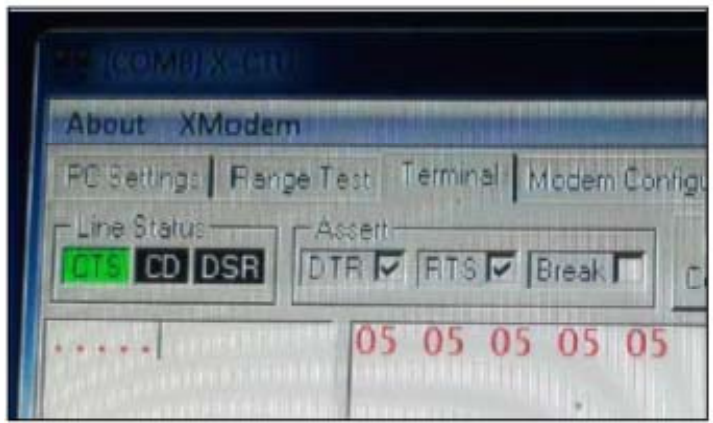

Figure 7. X-CTU application display

The testing of controller application is conducted by way of connecting XBee-PRO receiver on Quadruped Robot with PC and activates X-CTU application on the PC. It is aimed to read the result data received by XBee-PRO receiver from XBee-PRO transmitter through terminal facility on X-CTU application [5]. By conducting the testing toward the transmission of 5 samples command data, trial result is obtained which is summarized show in Table 2. Based on the data obtained, data value which is being sent and the amount of data being sent is matching, so that controller application has been running well.

Table 2. The trial result of transmitting command data

\begin{tabular}{cccccc}
\hline No. & Button & Value sent & $\begin{array}{c}\text { Value } \\
\text { received }\end{array}$ & $\begin{array}{c}\text { Amount of data } \\
\text { sent }\end{array}$ & $\begin{array}{c}\text { Amount of data } \\
\text { received }\end{array}$ \\
\hline 1 & Forward & 2 & 2 & 5 & 5 \\
2 & Right & 4 & 4 & 5 & 5 \\
3 & Backward & 1 & 1 & 5 & 5 \\
4 & Left & 3 & 3 & 5 & 5 \\
5 & Standby & 5 & 5 & 5 & 5 \\
\hline
\end{tabular}


The display result of video display application is shown on Figure 8 . The numbering in red on Figure 8 is intended to simplify the description regarding function of each facility owned by video display application.

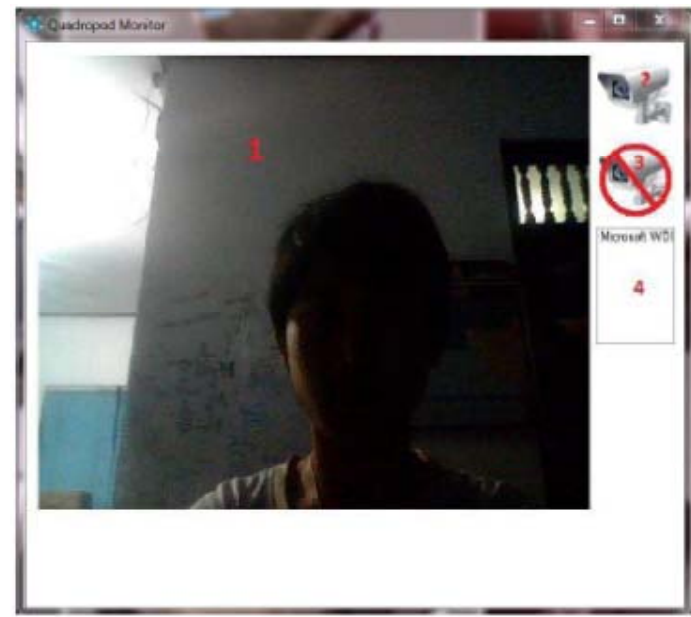

Figure 8. Video application display preview

The description of each video display application facility is in accordance with the numbering being stated, as follows:

1. Monitor to display the picture being sent by camera transmitter presence on Quadruped Robot.

2. Button to activate the process of image capture from camera transmitter and then to display it to the monitor.

3. Button to turn off the process of capturing and displaying image.

4. Text Box which displays directory to capture image data sent by camera transmitter on Quadruped Robot.

The testing of video display application is carried out by capturing the image directly from Windows camera through wireless camera receiver. The trial result can be seen in Figure 9. Based on the result obtained, it can be seen that video display application has succeeded to display video or live view captured by wireless camera. Based on the testing toward all of control facilities in providing the command to Quadruped Robot, the result is obtained that Quadruped Robot can perform the movement which is matching with command value given on controller software well. [9]

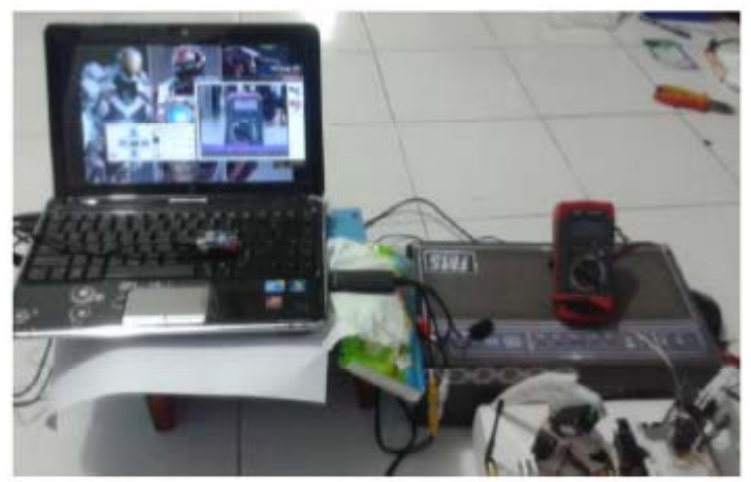

Figure 9. Video display application preview

\section{CONCLUSION}

Based on the result of the design of remote control system application based on Windows operating system to drive quadruped robot, some conclusions can be taken namely: 
1. Controller application can provide and send command value well to the Quadruped Robot.

2. The utilization of video display application can help the controlling of Quadruped Robot movement when Quadruped Robot is not within the range of view, or blocked by certain thing.

\section{ACKNOWLEDGEMENTS}

I would like to express my very great appreciation to robotic team work of Electrical and Computer Engineering Department, Udayana Univerrsity. All of suggestions during the planning, doing of this research work, and also their willingness to give their time so generously must very much appreciated.

\section{REFERENCES}

[1] Andrianto H, 2008, "Pemrograman Mikrokontroler AVR ATmega16 Menggunakan Bahasa C [CodeVision AVR]," Bandung : Informatika Bandung

[2] Anonim. 2005. XBee ${ }^{\circledR} \& X B e e-P R O{ }^{\circledR}$ 802.15.4 OEM RF Modules. [cited 2013 November 7 ]. AvaliableFrom : URL; http://www.cytron.com.my/datasheet/WirelessDevice/manual_xb_oemrfmodules_802.15.4.pdf

[3] Anonim.2010. Sinyal PWM. [cited 2013 November 8 ]. Avaliable From : URL; www.elektronika-dasar.web.id.

[4] Anonim. 2012. ATmega1280 datasheet. [cited 2013 October 28]. Available From : URL; http://www.atmel.com/Images/doc2549.pdf

[5] Ardika, K. 2013. "Perancangan SistemKendali Mobile Robot Jarak Jauh Menggunakan Wireless XBee-PRO Series $160 \mathrm{~mW}$ Berbasis Mikrokontroller ATmega32”.(Skripsi).Bali : Program Sarjana Universitas Udayana

[6] ATMEL Corporation, 2012, 8-bit Atmel Microcontroller with 64K/128K/256K Bytes In System Programmable Flash, http://www.atmel.com/images/doc2549.pdf, (diakses tanggal 4 September 2014).

[7] Heryanto, M.A dan Wisnu, A.P., 2007, "Pemrograman Bahasa C untuk Mikrokontroler ATmega" Yogyakarta: Andi.

[8] Kurniawan, E., 2011, Cepat Mahir Visual Basic. Yogyakarta: Andi.

[9] Shamsheer Verma, Chahat Deep Singh, Arvind Rehalia, 2014, Fully Automous and Controlled Quadraped Having Detection and Tracking, International Journal of Engineering and Technical Research (IJETR), ISSN: 2321-0869, Volume-2, Issue-9, September 2014

[10] Sidik Nurcahyo, 2012, “Aplikasi dan Teknik Pemrograman Mikrokontroler AVR Atmel,” Yogyakarta: Andi. 